\title{
Research on Cloud-based Business English Practical system
}

\author{
Jiayi $\mathrm{Wu}^{1, a,{ }^{*}, \text { Haijun Wang }}{ }^{2, b}$ \\ ${ }^{1}$ School of foreign language, Wuhan Business University, Wuhan 430056, China \\ 2 School of Computer, Hubei University of Education, Wuhan 430205, China \\ aarthurwujiayi@hotmail.com, bwanghaijun1977@126.com
}

\begin{abstract}
Keywords: Cloud Platform, Business English, Practical system, E-portfolio; Blended Teaching Model.
\end{abstract}

\begin{abstract}
Recently, Business English drove on a fast track and a gap of the related talents emerged in the human resources market. However, Business English Major fell behind the market comparatively. The inefficiency of the practical system is the main constraint on development. Fortunately, Cloud platform provides a suitable way to design a more efficient Practical system. In this paper, the adverse factors of Business English Practical system in application-oriented universities is analyzed and a new Practical system Model based on Cloud Platform is introduced, which combines with E-portfolio and blended teaching method to improve the practice results innovatively.
\end{abstract}

\section{Introduction}

As for application-oriented universities, practical system is normally essential in education. It is the major way to help students improve practical capability and creativity spirit, which combines knowledge, skills and technical qualifications. However, along with the expansion of higher education, the inadequate educational investment became a prominent issue which causes a deteriorating condition of practical training [1]. The situation is even worse in Business English major. In addition, practical training process is a complicated activity with individual behavior, group behavior and administration behavior including planning, experiment, simulation and internship. In Business English training process, it is hard to monitor the practical quality as it appears in the whole education procedures with the features of multiple levels, long cycle period and dispersed training tasks [2]. Therefore, it is vital to explore a more efficient Business English practical system in order to improve the education quality.

Along with the development of cloud platform, a new teaching model emerged which is named cloud-based teaching model and played an important role nowadays in higher education in formalization [3]. However, there are few researches on cloud-based Business English teaching model which could be a constraint on development of Business English major: (1) English teaching has gradually focused on the training and improvement of communication skills. Teachers tended to be more students-oriented in the class in order to increase the ratio of practical training even in theoretical courses. As to application-oriented universities, the ratio has already been at high level, but the effectiveness of the practical training was not satisfied. This was normally caused by the following factors: Lack of training resources. The development of Business English major was just on the fast track recent years. The former training resources are commonly from international trade, because it is the origin of Business English. However, it is not enough to suit the modern business communications as it has already extended into Management, Human Resources, Marketing, Logistics, Customer Relations and so forth. (2) Decentralization of the training courses. According to the investigation, the training period account for $35 \%$ to $40 \%$ in total credit hours. In reality, every trainer would spontaneously focus on one's own training course without consideration of other courses. From the perspective of the practical system, each course is an isolated island in the sea. Thus, both teachers and students do not know the effectiveness of the training which will certainly cause a negative influence to the pertinence of the training. (3) Mass training programs. Practical training is a process of self-construction for the students which emphasizes autonomous learning. But, 
sometimes, training became a hasty formalism, let alone personalized programs. Actually, according to Krashen's Input Hypothesis, it is better to acquire language if the students get $i+1$ language input. But the mass training programs cannot meet the demand which will naturally lead to an ineffective practical training.

\section{Cloud-based practical model}

\subsection{Establishment of resources platform}

Cloud platform provide a helpful solution to eliminate the ill effects of the three negative factors mentioned above [4]. In order to realize the plan, a practical model is designed, which includes four key factors. In this model, all the information and resources are stored in a resources platform as can be seen from the Figure 1, which can be enlarged continuously. Both teachers and students can upload documents, PowerPoint, pictures or video on the platform, which make the practical resources enlarge sufficiently for the Business English majors. Meanwhile, all the teachers and students can share all the resources and use them at the furthest level. It is a key function of cloud platform.

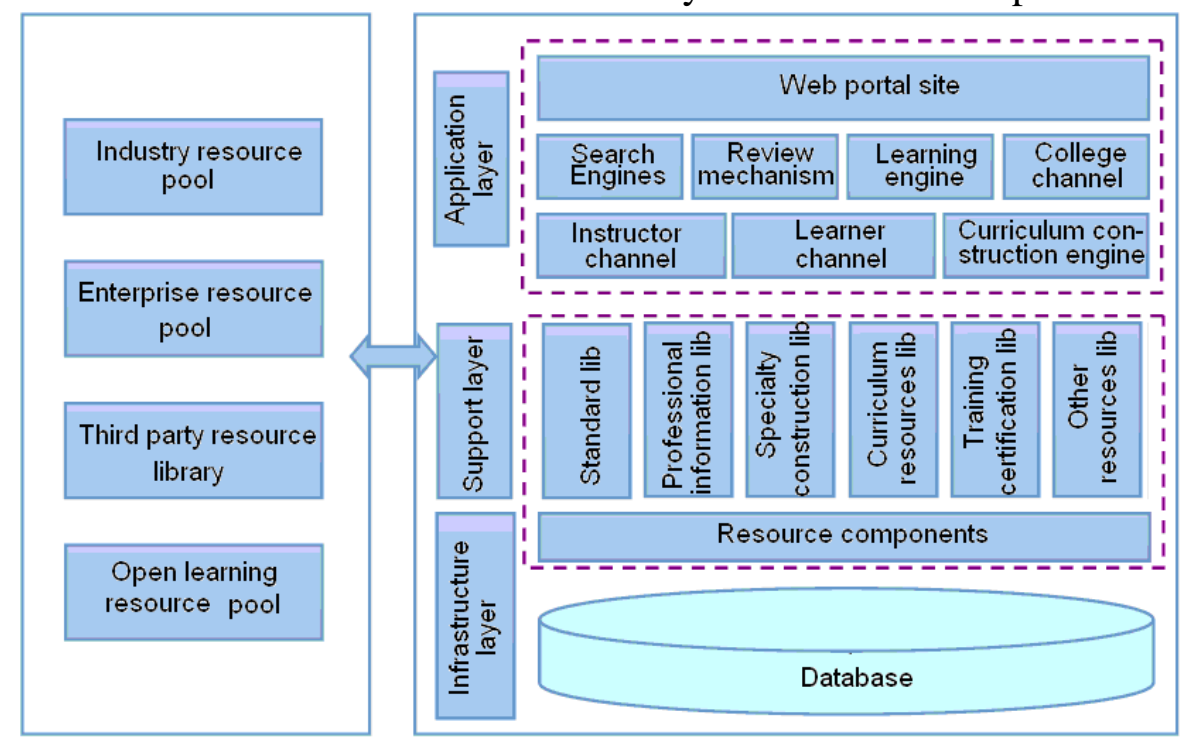

Fig. 1 The architecture of Resource platform

For example, in the training procedure of Business English Course, teachers took videos of students' presentations, and then upload on the resources platform. Other teachers could conclude and analyze students' problems in terms of pronunciation, intonation and so forth. In addition, teachers could found the solutions to the students' problems based on the analysis and help students overcome the language weaknesses.

\subsection{Design of curriculum system}

Cloud platform can integrate the decentralized courses and systemize the curriculum. According to the talents' development objective, Business English majored in management and business translation, in which management includes accounting, human resources, marketing and negotiating. Therefore, Business English major students need two skills: inter-cultural communication and translation. In order to improve the two skills, following the features of the courses, the author classified all the curriculums into two catalogues. One is to meet the requirements of inter-cultural communication that comprise courses of Pronunciation, Listening, Oral Practice, Business English and Inter-cultural communication. The other one is to meet the requirements of business translation, including Business English Reading, Business Correspondence Writing, and Business Translation. Courses in each catalogue will upgrade step by step, which can make the practical results serve for the subsequent training courses and integrate the entire training program.

\subsection{Introduction of E-portfolio}

In order to systemize the decentralized training courses in a more effective way and make it easier for the teachers to provide personalized training programs, with the cloud platform, the author introduced E-portfolio to Business English practical system. In brief, E-portfolio is a tool which 
allows students to store their training output on the cloud platform. With the E-portfolio, students can check and assess their own performance.

In Business English practical model, when designing each training program, teachers classified the training programs into three levels. Level A has the highest requirements, level $\mathrm{B}$ stay at the middle place, and level $\mathrm{C}$ is the lowest one. At the beginning of the practical training, every student would set up an individual E-portfolio. It would record students' training procedures like time, frequency, results etc. Based on the assessment of one training course, the E-portfolio would recommend a level of the subsequent training course. Therefore, one training course has a closer relationship with each other for the students. Meanwhile, teachers, with the E-portfolio, can better monitor the performance of the students, and provide a differentiate training which will lead to a better individual practical effectiveness.

\subsection{Adoption of blended teaching method}

Besides the three factors mentioned above, with the help of cloud platform, teachers can realize the $\mathrm{O} 2 \mathrm{O}$ blended teaching method. Teachers can store the training resources on the platform, so the students can finish the training programs online. After that, teachers can help the students analyze the key contents and difficulties offline in the classroom which will realize the interaction of online and offline. Also, teachers can transfer the theory instruction to micro lectures. Therefore, students can watch them on net or via mobile devices in spare time which will extend the learning range by fragmentation of Business English learning. Then, it becomes a complete circle from E-portfolio to integrated assessment, from online to offline.

\section{Application of the designed practical system}

Practical system based on cloud platform emphasize more on the procedure of the training not only the result. It will stimulate the students' learning autonomy on the one hand; on the other hand, it will increase the learning efficiency per unit time. Base on cloud platform, students can make selfassessment every week in the practical system. At the same time, teachers can also give each student a score as the training assessment. As can be seen from the Chart 1 and Chart 2the average scores and variance of students' self-assessment and teachers' assessment are calculated with the statistic method, and the effectiveness of the practical model is evaluated.

According to the comparison, it is shown that there is an upward trend of the score on the learning effectiveness made by both students and teachers. In the view of the students, the average score of the self-assessment increased 6.95 compare with the start of the semester, which means students believe that their business English proficiency has improved. It has a similar trend in terms of the assessment from teachers, which raised 10.69. In addition, the decrease of the variance of the students score proved that lower English level students obviously improve their Business English skills with the benefits of the platform, and the gap between the lower English level students and the higher English level students became smaller and smaller.

Table 1 the score of chosen 10 students at random in different weeks

\begin{tabular}{|c|c|c|c|c|c|c|}
\multirow{2}{*}{ Score } & \multicolumn{2}{|c|}{ Week 3 } & \multicolumn{2}{c|}{ Week 9 } & \multicolumn{2}{c|}{ Week 16 } \\
\cline { 2 - 7 } Student & Self-assess & Teacher & Self-assess & Teacher & Self-assess & Teacher \\
\hline Student A & 80 & 76 & 83 & 80 & 87 & 86.5 \\
\hline Student B & 77 & 78 & 83 & 84.5 & 90 & 89 \\
\hline Student C & 85 & 83 & 88 & 87 & 92 & 90 \\
\hline Student D & 80 & 82 & 86 & 83.5 & 90 & 88 \\
\hline Student E & 80 & 81 & 85 & 87 & 91 & 92 \\
\hline Student F & 77 & 75 & 80 & 78 & 80 & 81 \\
\hline Student G & 83 & 84 & 90 & 90 & 95 & 92 \\
\hline Student H & 87 & 88 & 90 & 92 & 93 & 95 \\
\hline Student I & 84 & 83.5 & 87 & 85 & 90 & 89.5 \\
\hline Student J & 75 & 70 & 82 & 77.5 & 83 & 84 \\
\hline
\end{tabular}


Table 2 Comparison of all the students' average scores and variance in different weeks

\begin{tabular}{|c|c|c|c|c|c|c|}
\hline \multirow{2}{*}{} & \multicolumn{2}{|c|}{ Week 3 } & \multicolumn{2}{c|}{ Week 9 } & \multicolumn{2}{c|}{ Week 16 } \\
\cline { 2 - 6 } & Average & Variance & Average & Variance & Average & Variance \\
\hline Self-assess & 80.71 & 38.42 & 83.55 & 33.25 & 87.66 & 27.13 \\
\hline Teacher & 77.45 & 40.51 & 83.23 & 36.53 & 88.14 & 25.49 \\
\hline
\end{tabular}

The two charts reflect the advantages of the application as follows:

- Enhance the confidence and level of Business English communication. Along with the finished training programs on cloud, students can examine the procedure of their own training and find their strengths and weaknesses objectively. Therefore, they can practice more on their weaknesses by plenty of training and feedback in order to improve the communication skills.

- Meet the demand of personalized learning. With the blended teaching method and the introduction of the E-portfolio, teachers can provide personalized training programs to individuals. It will continuously promote the practical effectiveness.

- Increase the learning enthusiasm. Students can access to kinds of resources on cloud, which will make the training programs more vivid. Commonly, students say that they are more willing to take part in the training programs. Meanwhile, the introduction of the E-portfolio make students place high priority to the training programs objectively.

\section{Conclusion}

This paper illustrates a new effective Business English practical system based on the cloud platform, which brings benefits for both teachers and students in the training process. However, the sample of the research is comparatively small and the investigation time is only one semester. Therefore, it is better to take a more elaborate investigation of the effectiveness in order to further improve the practical system.

\section{Acknowledgments}

This work was financially supported by a project from the Wuhan Academy of Education Sciences (No.2013A044) and a grant from the Hubei Provincial Department of Higher Education Teaching Reform Research (No.2016419).

\section{References}

[1]. Yacine Kessaci, Nouredine Melab, El-Ghazali Talbi. "A multi-start local search heuristic for an energy efficient VMs assignment on top of the Open Nebula cloud manager", Future Generation Computer System, 29(1), 1-20, 2013.

[2]. Alfonso Quarati, Andrea Clematis, Antonella Galizia, Daniele D' Agostino. "Hybrid Clouds brokering: Business opportunities, QoS and energy-saving issues", Simulation Modelling Practice and Theory, 39(3), 121-134, 2013.

[3]. R. Buyya, C.S. Yeo, S. Venugopal, J. Broberg, I. Brandic, “Cloud Computation and emerging IT platforms: vision, hype, and reality for delivering computation as the 5th utility", Future Generation Computer Systems, 25(6) ,599-616, 2009.

[4]. Vaquero L M, Rodero-merino L, Caceres J,et al. "A break in the Clouds: Towards a cloud definition,” SIGCOMM Computer Communication Review, 2009(39):137-150. 